NASZA DERMATOLOGIA Onlin OUR DERMATOLOGY Online

Source of Support: Nil

Competing Interests: None

\section{PEDICULOSIS CAPITIS}

Patricia Chang ${ }^{1}$, Gylari Calderón ${ }^{2}$

'Dermatologist at Hospital General de Enfermedades IGSS and Hospital Ángeles, Guatemala

${ }^{2}$ Dermatopathologist at Hospital General de Enfermedades IGSS and Hospital Ángeles Guatemala

Corresponding author: Patricia Chang, $\mathrm{MD} \mathrm{PhD}$

pchang2622@gmail.com
Pediculosis capitis is an infection of the hair and skin caused by the Pediculus humanus capitis [1].

Head-lice infestation is widely endemic, especially in children, are generally spread through direct head-to-head contact with an infected person [2].

Females get head lice twice more often than males and infestation in persons of Afro-Caribbean or other black descent is rare because of hair consistency [3].

The head lice infestation is Pediculus capitis scalp. 7-10 female eggs produced per day, the maximum number of eggs produced by female throughout its cycle is 110-140; this adheres their host eggs to hair by a water insoluble substance and glue-like. The live eggs (with embryo) are gray gelatinous and are located close to the scalp at 3-4 $\mathrm{mm}$ [4].

Scalp pruritus is the most common and characteristic manifestation of the head louse infection localized in retroauricular region, occiput and nape. Secondary bacterial infection (impetigo) may occur as a result of scratching with painful regional lymphadenitis [5].

The empty egg cases or nits can be identified, adult lice and nymphs may be seen in heavy infection [6].

The diagnosed is done by the presence of lice or eggs in the hair, trough using a magnifying glass or running a comb through the child's hair, dermatoscope and microscope [7].

There are different types of topical treatments available: chemical insecticides such as malathion or pyrethrins, physical acting products such as silicones (dimethicone) and so-called natural oils and essences type [8]. Ivermectin It should be administered at $200 \mathrm{mg} / \mathrm{kg}$, single dose. Some studies recommend repeat the dose at 7,10 or 15 days [9].

\section{Case 1}

Female patient 40 years old hospitalized due to cholecystectomy, during her clinical examination head louse was seen, dermatological examination showed the presence of lice and nits (Fig. 1a, b). Rest of the physical exam was normal.

\section{Case 2}

Female patient 50 years old hospitalized due to appendectomy, during her clinical examination head louse was seen, dermatological examination showed the presen ce of nits (Fig. 2a, b) and lice (Fig. 3 a, b), histopathology showed the morphology of an adult louse, head comprising an antenna and eye traces (Fig. 4) is also observed part of the chest showing fragments of the legs and abdomen of seven segments where you can see remains of the spiracles where respiration occurs (Fig. 5), at the bottom remains anus and genitalia (Fig. 6). Rest of the physical exam was normal.

Both patient received ivermectin $200 \mathrm{mg} / \mathrm{kg}$ one single dose and cured of their pediculosis capitis.

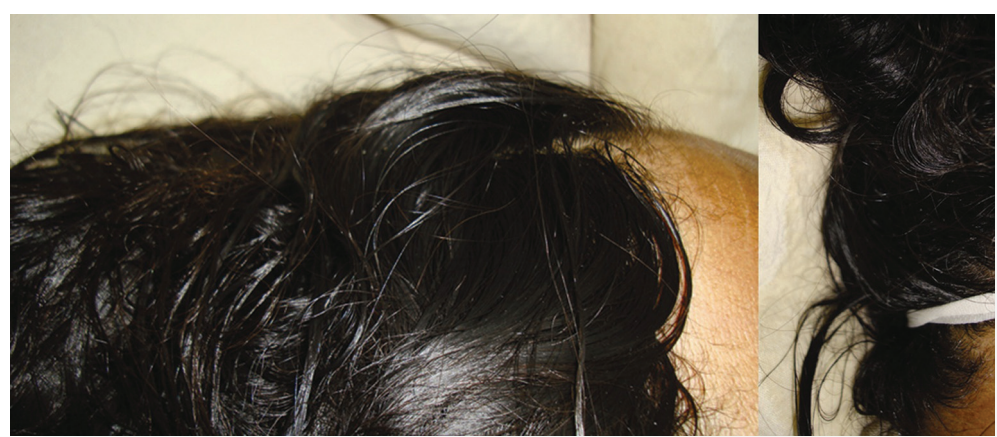

Figures 1a, b. Nits on hair in female patients (case 1). 


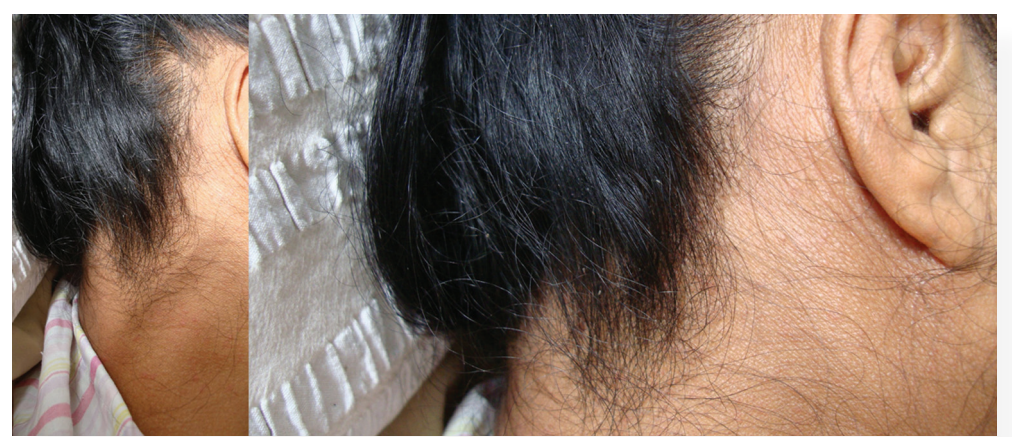

Figures 2a, b. Nits on hair in female patients (case 2).

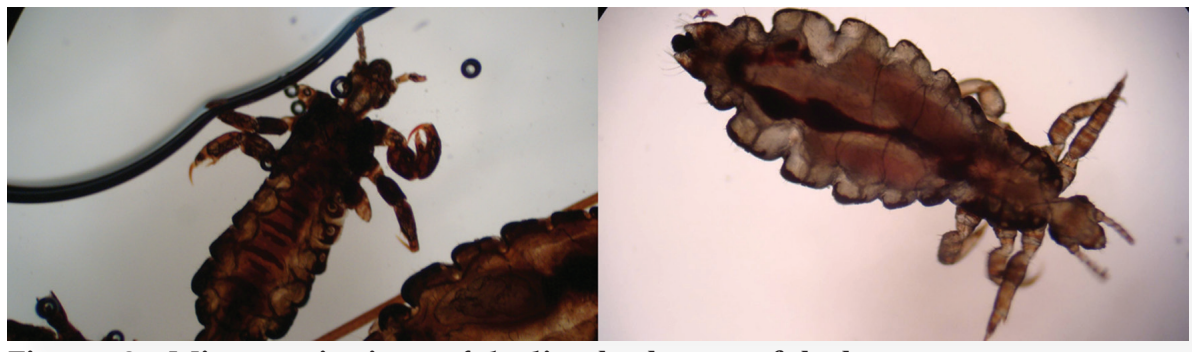

Figures 3a. Microscopic views of the lice. b. close up of the louse.

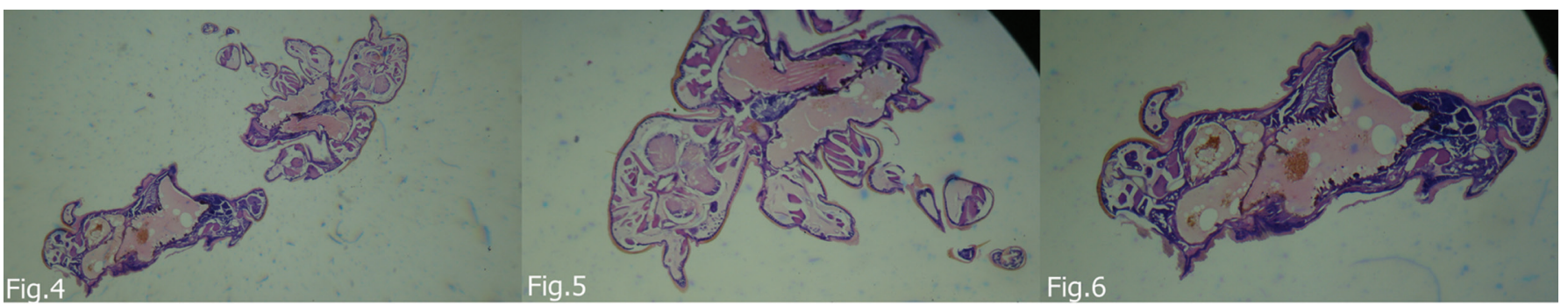

Figures 4. Histopathology showed the morphology of an adult louse, head comprising an antenna and eye traces.

Figures 5. It is also observed part of the chest showing fragments of the legs and abdomen of seven segments where you can see remains of the spiracles where respiration occurs.

Figures 6. At the bottom was observed remains anus and genitalia.

\section{REFERENCES}

1. Rapini RP, Bolognia JL, Jean L, Jorizzo JL: Dermatology: 2007. 2-Volume Set. St. Louis: Mosby.

2. Lajos R; Apari P: Why infest the loved ones - inherent human behaviour indicates former mutualism with head lice". Parasitology. 2012:139:696-700.

3. Nutanson I, Steen CJ, Schwartz RA, Janniger CK: Pediculus humanus capitis: an update. Acta Dermatovenerol Alp Panonica Adriat. 2008; 17:147-54, 156-7, 159.

4. Gairí J, Molina V, Moraga F, Viñallonga X. Baselga E: Pediculosis de la cabeza. Protocolos de la Asociación Española de Pediatría. 2006:55-64
5. Arenas R: Pediculosis. Atlas dermatología Diagnostico y tratamiento. McGraw-Hill. México. 2009: 564-8.

6. Rook Burns DA: Diseases caused by Arthropods and other Noxious Animals in Rook/Wilkinson/Ebling Textbook of Dermatology Blackwell Science London 1998: 1440-2.

7. Pollack RJ, Kiszewski AE, Spielman A: Overdiagnosis and consequent mismanagement of head louse infestations in North America. Pediatr Infect Dis J. 2000;19:689-93.

8. Actualización del tratamiento de la pediculosis. Infact. 2011:19:711.

9. Caro J, Zúñiga I: Pediculosis: Una ectoparasitosis emergente en México. Revista de Enfermedades Infecciosas en Pediatría. $2001 ; 24(94)$

Copyright by Patricia Chang, et al. This is an open access article distributed under the terms of the Creative Commons Attribution License, which permits unrestricted use, distribution, and reproduction in any medium, provided the original author and source are credited. 